\title{
Oceanic response to changes in the WAIS and astronomical forcing during the MIS31 superinterglacial
}

\author{
Flavio Justino $^{1}$, Douglas Lindemann ${ }^{1}$, Fred Kucharski ${ }^{2}$, Aaron Wilson ${ }^{3}$, David Bromwich ${ }^{3}$, and Frode Stordal ${ }^{4}$ \\ ${ }^{1}$ Department of Agricultural Engineering, Universidade Federal de Viçosa, Viçosa, Brazil \\ ${ }^{2}$ The Abdus Salam International Centre for Theoretical Physics, Trieste, Italy \\ ${ }^{3}$ Polar Meteorology Group, Byrd Polar and Climate Research Center, The Ohio State University, Columbus, OH, USA \\ ${ }^{4}$ University of Oslo Department of Geosciences, Oslo, Norway \\ Correspondence to: Flavio Justino (fjustino@ufv.br)
}

Received: 8 November 2016 - Discussion started: 24 November 2016

Revised: 4 July 2017 - Accepted: 19 July 2017 - Published: 1 September 2017

\begin{abstract}
Marine Isotope Stage 31 (MIS31, between 1085 and $1055 \mathrm{ka}$ ) was characterized by higher extratropical air temperatures and a substantial recession of polar glaciers compared to today. Paleoreconstructions and model simulations have increased the understanding of the MIS31 interval, but questions remain regarding the role of the Atlantic and Pacific oceans in modifying the climate associated with the variations in Earth's orbital parameters. Multi-century coupled climate simulations, with the astronomical configuration of the MIS31 and modified West Antarctic Ice Sheet (WAIS) topography, show an increase in the thermohaline flux and northward oceanic heat transport (OHT) in the Pacific Ocean. These oceanic changes are driven by anomalous atmospheric circulation and increased surface salinity in concert with a stronger meridional overturning circulation (MOC). The intensified northward OHT is responsible for up to $85 \%$ of the global OHT anomalies and contributes to the overall reduction in sea ice in the Northern Hemisphere (NH) due to Earth's astronomical configuration. The relative contributions of the Atlantic Ocean to global OHT and MOC anomalies are minor compared to those of the Pacific. However, sea ice changes are remarkable, highlighted by decreased (increased) cover in the Ross (Weddell) Sea but widespread reductions in sea ice across the $\mathrm{NH}$.
\end{abstract}

\section{Introduction}

Recent paleoreconstructions and climate modeling experiments have attempted to disentangle the influence of dominant forcing on past climates from orbital configurations (Yin, 2013; Erb et al., 2015) to the El Niño Southern Oscillation (ENSO) and ice sheet variability (Russon et al., 2011; DeConto et al., 2012). However, other issues, like air-sea coupling and its impact on atmospheric and oceanic variability (Knutti et al., 2004; Bush and Philander, 1998), require additional scrutiny. This two-way interaction implies that the atmosphere affects the sea surface conditions by modifying oceanic heat fluxes which in turn feed back into the lower tropospheric atmospheric flow (Timmermann et al., 1998).

The global climate response to these processes is governed by complex interactions occurring not only at the air-sea interface but also in sub-surface oceanic layers where a substantial amount of heat is stored (Meehl et al., 2011; Yin and Berger, 2012; Ganachaud and Wunsch, 2003). Therefore, fully coupled models are essential to reproduce the large-scale climatic features of these glacial and interglacial regimes (Erb et al., 2015; Otto-Bliesner et al., 2003). This is especially true when evaluating the climate response to potential changes in the meridional overturning circulation (MOC) and the oceanic heat transport (OHT; Shin et al., 2003). Increased OHT from the Pacific into the Arctic associated with changes in Antarctic ice volume has been argued to affect the Beringian climate during interglacial epochs (Coletti et al., 2015) and maintain warm high-latitude oceanic surface temperatures in many intervals throughout the geologic past (Comeau et al., 2016). 
Others have taken advantage of simplified climate models using an atmospheric general circulation model (GCM) coupled to a slab mixed-layer ocean model (Lunt et al., 2017; Coletti et al., 2015; Roychowdhury and DeConto, 2016). Though valid, this modeling approach reduces oceanatmosphere feedbacks that are crucial for the reorganization of atmospheric flow on long timescales. It has been emphasized by coupled modeling studies that oceanic dynamical changes related to orbital fluctuations are the primary forcing in determining large-scale atmospheric flow patterns (Erb et al., 2015; Tomas et al., 2016). Because oceanic dynamical changes during interglacial intervals are important for determining the large-scale atmospheric circulation and temperature distribution (Coletti et al., 2015), solutions to these issues are pursued here by employing the International Centre for Theoretical Physics Coupled Global Climate Model (ICTP-CGCM; Kucharski et al., 2015).

An interesting test case to explore these climate feedbacks is the Marine Isotope Stage 31 interval (MIS31), which occurred at $\sim 1080 \mathrm{kaBP}$ (Lisiecki and Raymo, 2005). This epoch has been characterized by warmer global air temperatures and substantial melting of polar glaciers compared to today (Melles et al., 2012; Wet et al., 2016). However, paleoreconstructions and modeling results disagree with respect to the North Hemisphere (NH) warming during MIS31, suggesting the need for a better understanding of this interglacial and other warmer climates as discussed by Melles et al. (2012) and Coletti et al. (2015).

Analyses have focused on the climate response to individual drivers of the interglacial climates (Knorr and Lohmann, 2014; Yin and Berger, 2012; Pollard and DeConto, 2009; Villa et al., 2008). Among other effects, insolation has been shown to play the dominant role in defining high-northernlatitude temperature and sea ice (Yin and Berger, 2012). The longitude of the perihelion (precession) is also found to lead changes in the equatorial Pacific seasonal cycle (Erb et al., 2015). Meanwhile, past fluctuations in atmospheric $\mathrm{CO}_{2}$ concentration have been claimed to induce long-term surface and deep water temperature trends (Knorr and Lohmann, 2014). Accordingly, this study aims to disentangle the individual contributions of the West Antarctic Ice Sheet (WAIS) and the astronomical configuration during the MIS31 interglacial climate by applying a coupled climate model. Mechanisms related to the combined effects of these forcings on the MIS31 climate are explored, including the interhemispheric coupling, the potential role of OHT, and wind-driven and thermohaline changes in oceanic circulation.

\section{Coupled model and experimental design}

The coupled climate model utilized is the ICTP-CGCM, consisting of the atmospheric global climate model SPEEDY version 41 (Kucharski et al., 2006) coupled to the Nucleus for European Modelling of the Ocean (NEMO) model (Madec,
2008) with the OASIS3 coupler (Valcke, 2013). The atmospheric component runs at $\mathrm{T} 30$ horizontal resolution and there are eight levels in the vertical. The model includes physically based parameterizations of large-scale condensation, shallow and deep convection, shortwave and longwave radiation, surface fluxes of momentum, heat and moisture, and vertical diffusion.

NEMO is a primitive equation $z$-level ocean model based on the hydrostatic and Boussinesq approximations. This version applies a horizontal resolution of $2^{\circ}$ and a tropical refinement to $0.5^{\circ}$. The ocean component has 31 vertical levels with layer thicknesses ranging from $10 \mathrm{~m}$ at the surface to $500 \mathrm{~m}$ at the ocean bottom (16 levels in the upper $200 \mathrm{~m}$ ). Additional details of the ICTP-CGCM are described by Justino et al. (2015) and Kucharski et al. (2015).

The ICTP-CGCM control simulation (CTR) is run under present day orbital forcing for over 2000 years since proper evaluations of long-term ocean-atmosphere processes require statistical equilibrium representation of the climate state, particularly for paleoclimatic features in a coupled atmosphere-ocean model (Peltier and Solheim, 2004). The $\mathrm{CO}_{2}$ concentration in our CTR climate is $325 \mathrm{ppm}$ as it characterizes anthropogenic emissions of $\mathrm{CO}_{2}$ by the year 1950 but does not include the accelerated increase that occurred by the end of the 20th century.

\subsection{Model performance of the CTR climate}

To evaluate the reliability of the ICTP-CGCM to represent the present day climate (control run), Fig. 1 shows sea surface temperature (SST) differences between the CTR run and the NOAA Optimum Interpolation (OI) SST V2 (NOAAOI-SST-V2; Reynolds et al., 2002) and sea ice area based on the Hadley Centre Sea Ice and SST data set (HadISST; Rayner et al., 2003). The control run has been simulated for 1000 years and CTR climatology is based on the last 100 years. The modeled evaporation minus precipitation $(E-P)$ flux is compared to the Interim Reanalysis from the European Centre for Medium-Range Weather Forecasts (ECMWF) ERA-Interim (ERAI; Dee et al., 2011). Kucharski et al. (2015) have provided detailed analyses of the present day climate simulated by the ICTP-CGCM.

Figure 1a shows that annual SSTs in the ICTP-CGCM are lower than NOAA-OI-SST-V2 and are related to differences in the lower tropospheric flow. In fact, the zonal wind over the NH storm track region in ICTP-CGCM and over the Southern Hemisphere ( $\mathrm{SH})$ polar jet are weaker than in ERAI by up to $\pm 4 \mathrm{~ms}^{-1}$. In the $\mathrm{NH}$ during the summer season, this is associated with reduced temperature advection from Asia and North America onto the North Atlantic and Pacific, leading to lower ICTP-CGCM SSTs. However, it should be stressed that overall SST differences are in the range of $\pm 2{ }^{\circ} \mathrm{C}$.

Analysis of $E-P$ flux demonstrates that our coupled model reproduces the main characteristics of the ERAI 
(a)

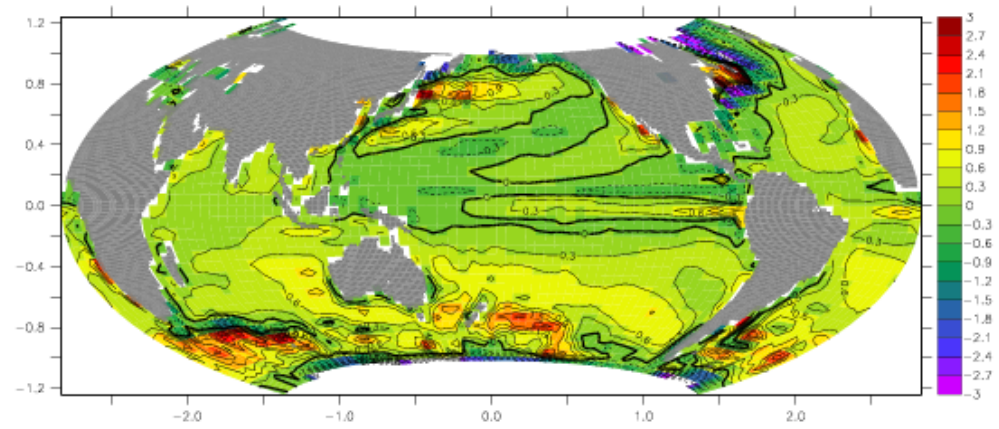

(b)

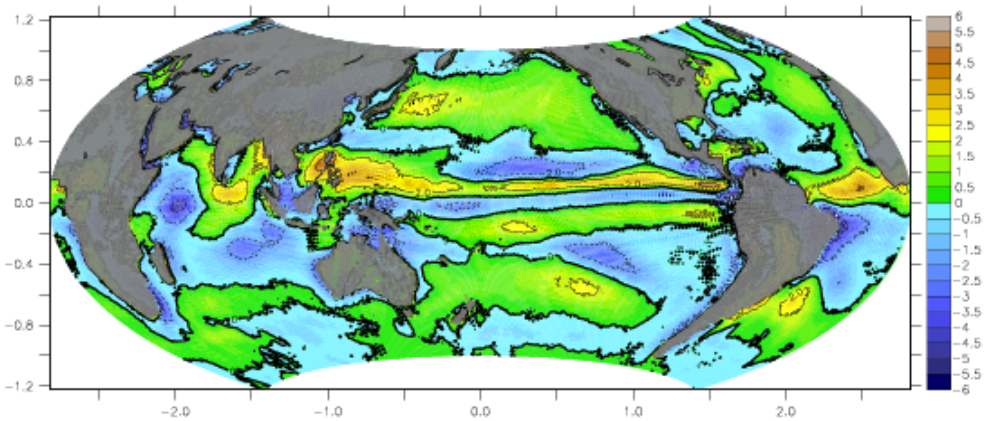

(c)

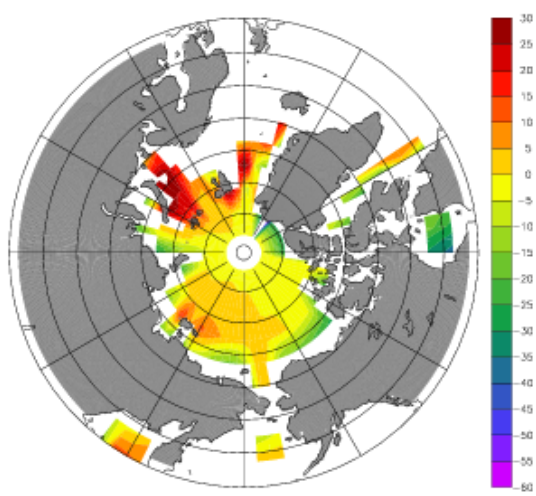

(d)

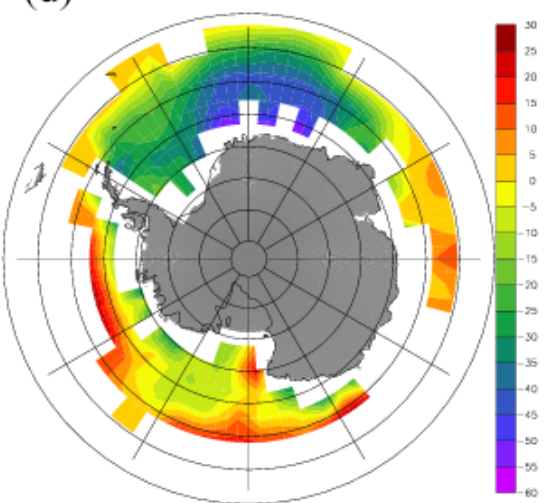

Figure 1. (a) Sea surface temperature differences $\left({ }^{\circ} \mathrm{C}\right)$ between the CTR and the NOAA OI Sea Surface Temperature V2. (b) $E-P$ flux differences $\left(\mathrm{mm} \mathrm{day}^{-1}\right)$ between the control simulation and the ERAI. Sea ice area differences $(\%)$ between the CTR and the HadISST estimates for the (c) Northern Hemisphere and (d) Southern Hemisphere.

$E-P$ flux (Fig. 1b), but the zonal averages reveal that the ICTP-CGCM is wetter than the ERAI in the equatorial belt and SH midlatitudes (not shown). However, differences are less than $1 \mathrm{~mm} \mathrm{day}^{-1}$. This implies that the $E-P$ flux associated with the intertropical convergence zone (ITCZ) needs improvements in order to better reproduce equatorial climate dynamics, including decreased precipitation in the Pacific warm pool and over the southern part of the South Atlantic. Nevertheless, this is a recurrent feature in other CGCMs (JiaJin, 2007).

Comparison of the ICTP-CGCM sea ice area with estimates from the Hadley Centre counterpart shows that the ICTP-CGCM does a reasonable job in both hemispheres for December-January-February (DJF) and June-July-August (JJA; Table 1). Sea ice area is computed as the total area covered by ice, which corresponds to sum of the area of each cell multiplied by the fractional concentration for that cell. Insofar as annual mean conditions are concerned (Fig. 1c and d), limitations are evident as ICTP-CGCM is dominated by higher sea ice concentration than demonstrated by the Hadley Centre across most of the NH, particularly in the Russian
Arctic (Fig. 1c). In the SH, our model shows a lower concentration of ice in the Atlantic polar region but a higher concentration in the sea ice edge in extratropical latitudes around $60^{\circ} \mathrm{S}$ and near the Ross Sea (Fig. 1d). The ICTPCGCM exhibits a higher amplitude in the seasonal cycle of sea ice thickness in the Weddell Sea compared to HadISST with thinner sea ice in summer (not shown).

Several investigations have demonstrated that extratropical SST and sea ice are currently among the largest limitations in Earth climate modeling. Based on the Coordinated Ocean-ice Reference Experiments (CORE) model intercomparison, Griffies et al. (2009) found that models generally have large biases in all fields, such as SST, sea surface salinity (SSS), sea ice, and zonal velocity in the equatorial Pacific subsurface. Though models show a substantial spread in skill depicting the Atlantic Meridional Overturning Circulation (AMOC), Kiel ORCA performs very well. The ICTPCGCM, which is a coupled ocean-atmosphere model, applies the same Kiel ORCA ocean component, and the ICTPCGCM biases are in the lower range compared to other CORE models. 
Table 1. Sea ice area $\left(10^{9} \mathrm{~m}^{2}\right)$ in the NH and SH for the Hadley Centre Sea Ice (in brackets), CTR, and differences between the sensitivity experiments and CTR. Values with asterisks are statistically significant at $95 \%$ based on $t$-test statistics.

\begin{tabular}{lrr|rr}
\hline & \multicolumn{2}{c|}{ NH } & \multicolumn{2}{c}{ SH } \\
\cline { 2 - 5 } & DJF & JJA & DJF & JJA \\
\hline CTR (Hadley) & $13.09(13.36)$ & $8.23(8.68)$ & $4.90(5.10)$ & $13.93(13.08)$ \\
TOPO-CTR & 0.8 & 0.5 & 0.03 & 0.4 \\
AST-CTR & $-1.3^{*}$ & $-4.0^{*}$ & 0.9 & 1.6 \\
MIS31-CTR & $-1.4^{*}$ & $-4.2^{*}$ & 1.3 & 2.3 \\
\hline
\end{tabular}

The importance of the air-sea coupling at the atmosphereocean interface has long been recognized, and the impacts on the Ekman layer must be accounted for in models. CGCMs driven by a low-resolution oceanic component are very limited in their ability to reproduce the wind-driven upwelling (Dawson et al., 2013) and are therefore warmer than models of higher resolution. More importantly, low-resolution atmosphere-ocean models struggle to reproduce the OHT. Thus, these models simulate weaker AMOC, allowing a larger storage of heat in the $\mathrm{SH}$ due to the $\mathrm{NH}$ heat piracy assumption (Broecker, 1998).

\section{Design of the sensitivity experiments}

To evaluate the impacts on climate due to changes in the WAIS topography and the astronomical forcing during the MIS31 interglacial, three additional sensitivity experiments have been conducted. Analyses have been carried out for the last 100 years of these 1000-year simulations. The astronomical forcing is assumed to represent $1072 \mathrm{ka}$ based on the warmest summer month in the Lake El'gygytgyn reconstruction (Coletti et al., 2015; Melles et al., 2012; Table S1 in the Supplement):

1. TOPO applies the MIS31 WAIS topography as proposed by previous studies (Pollard and DeConto, 2009; Justino et al., 2015);

2. AST is conducted with the astronomical configuration characteristics of $1072 \mathrm{ka}$ (Berger, 1978; Coletti et al., 2015);

3. and MIS31 is the combined effect of the forcing described in TOPO and AST.

In all sensitivity experiments the $\mathrm{CO}_{2}$ concentration is set to $325 \mathrm{ppm}$. For the MIS31 interval, this is reasonable based on boron isotopes in planktonic foraminifera shells (Honisch et al., 2009). The $\mathrm{CO}_{2}$ concentration during MIS31 could have varied between 300 and $350 \mathrm{ppm}$ due to propagated error in the individual $\mathrm{pH}$, SST, salinity, and alkalinity in the reconstructions. This variation in the amount of atmospheric $\mathrm{CO}_{2}$ may lead to an overestimation in the $\mathrm{NH}$ warming as simulated in our study. Changes in $\mathrm{CO}_{2}$ by about $+50 \mathrm{ppm}$ may be associated with a $+0.3 \mathrm{~K}$ change in globally averaged surface temperature, but this change in temperature is within the uncertainty of the climate sensitivity (Bindoff et al., 2013). The concentration of $\mathrm{CH}_{4}\left(\mathrm{~N}_{2} \mathrm{O}\right)$ is 800 (288) ppb (Schilt et al., 2010; Loulergue et al., 2008); this is similar to values proposed by Coletti et al. (2015).

Since the Greenland Ice Sheet (GIS) was only slightly smaller during MIS5e than current conditions, Dahl-Jensen et al. (2013) and Coletti et al. (2015) showed that MIS5e and MIS31 differed by only $0.6^{\circ} \mathrm{C}$, and thus the GIS in our MIS31 simulations reflects present day conditions. However, our simulation does not include changes in oceanic gateways because there is no conclusive global land-sea mask reconstruction for the MIS31 interval. The WAIS topography has been modified, but no changes in sea level have been applied in our modeling experiment.

The modified WAIS reflects sea water albedo in the sensitivity runs, and changes in the initial salinity field in response to the WAIS collapse have not been included. Aiken (2008) demonstrated the limited response of the climate system to the freshening implied by Antarctic sea ice melt, even in the presence of a much larger freshwater forcing of approximately 0.4 Sv. Moreover, Vaughan and Arthern (2007) argued that an outflow rate associated with WAIS melting is not realistically attainable, making it difficult to implement in a freshwater forcing experiment. Insofar as the WAIS collapse is concerned, this study focuses on analyzing the climate response to mechanical changes in orography.

\section{Climate response to MIS31 forcing}

\subsection{The WAIS collapse}

Previous work by Justino et al. (2015) using a simplified lowresolution ocean model $\left(3^{\circ} \times 3^{\circ}\right)$ has demonstrated that the incorporation of a modified WAIS topography, characteristic of the MIS31 interval, results in generally warmer global surface temperatures compared to the current climate with enhanced positive anomalies between 50 and $70^{\circ} \mathrm{S}$.

Under present day conditions, katabatic winds flowing offshore from the continent over the Weddell Sea contribute to the maintenance of cold air over the sea ice edge (Mathiot et al., 2010). Modeled Weddell Sea warming in the TOPO 

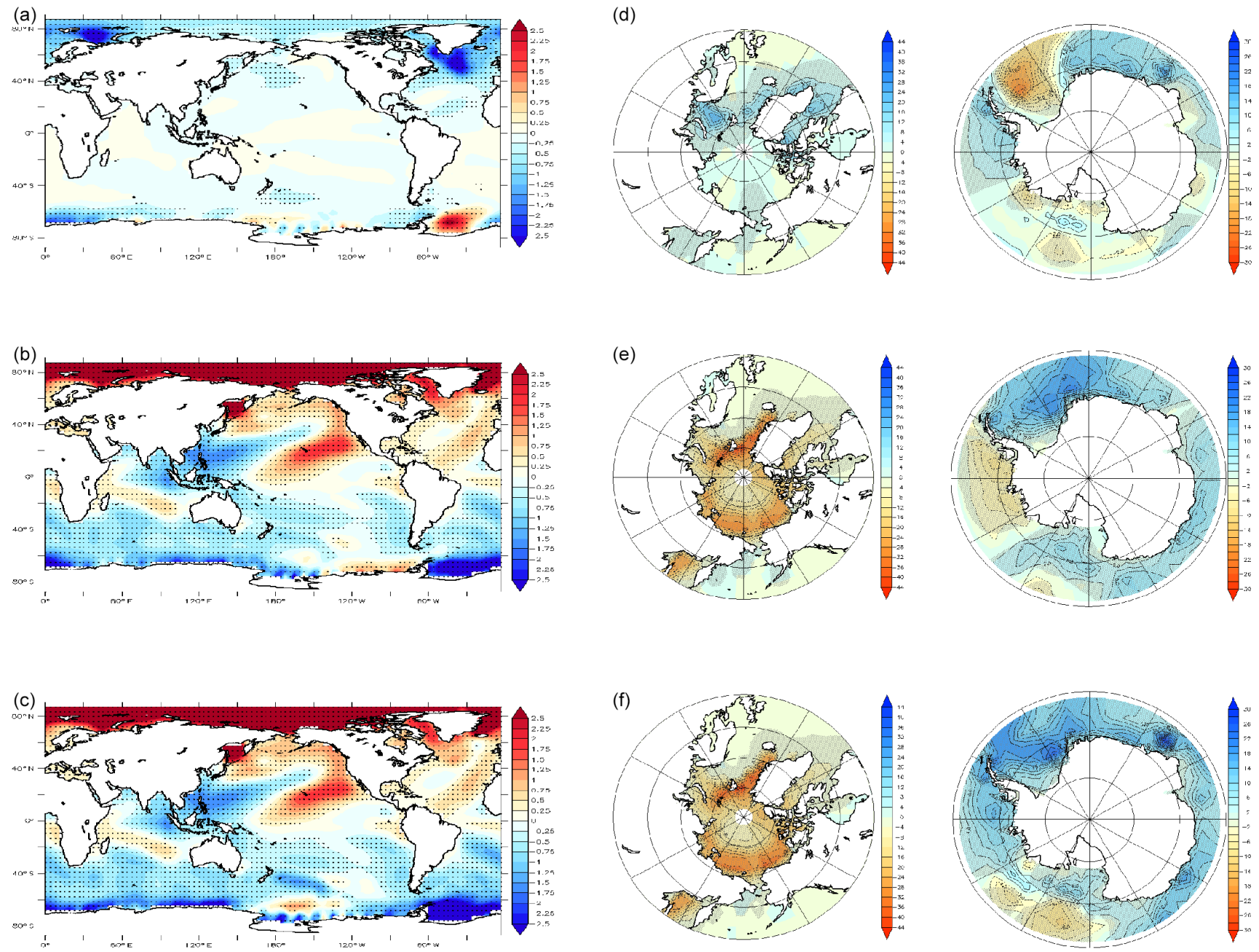

Figure 2. Surface temperature differences $\left({ }^{\circ} \mathrm{C}\right)$ between (a) TOPO, (b) AST, and (c) MIS31 compared to the CTR. Panels (d, e, f) are the same as $(\mathbf{a}, \mathbf{b}, \mathbf{c})$ but for sea ice differences $(\%)$. The dotted areas in panels $(\mathbf{a}, \mathbf{b}, \mathbf{c})$ and hatched areas in panels $(\mathbf{d}, \mathbf{e}, \mathbf{f})$ are significant at $95 \%$ based on $t$-test statistics.

simulation is related to weaker katabatic winds and reduced continental cold air advection due to a collapsed WAIS (Justino et al., 2015). During periods of reduced sea ice thickness, there is an increase in the heat flux from the ocean to the atmosphere. This increases the convective mixing and warms the overlying atmosphere. Higher surface temperatures in the Ross Sea in TOPO than seen in the CTR simulation are supported by the Ocean Drilling Program (ODP) site 1165 and by the marine glacial record of the AND-1B sediment core in the Ross Ice Shelf (Naish et al., 2009).

The WAIS collapse also leads to cooling in the North Atlantic. Temperature anomalies of opposite sign between the North and South Atlantic have been a recurrent feature in the Earth's climate. This dipole is related to the North Atlantic freshening (Knutti et al., 2004) and associated with the modification of the SH wind patterns and subsequent winddriven circulation (Speich et al., 2007). In both situations, changes involve anomalous patterns of OHT. Seasonal sea ice changes (DJF and JJA) between TOPO and CTR show areal increases in both hemispheres with larger changes in the NH (Table 1). Annually averaged sea ice changes due to the WAIS collapse are noted in the Labrador and Nordic seas that are statistically significant at $95 \%$. In the SH, the impact of the WAIS collapse is seen in the majority of the polar region (Fig. 2d). The fact that annual changes are mostly statistically significant and changes in DJF and JJA are not indicates that processes during autumn and spring play important roles in modulating annual sea ice conditions in the WAIS simulation.

It should be noted that the warming indicated by the current ICTP-CGCM TOPO simulation (Fig. 2a) is substantially smaller than the results presented by Justino et al. (2015). There are several factors related to these differences. Justino et al. (2015) show much weaker SH westerly flow that leads 
to warmer SSTs across the high latitudes of the SH compared to the present study (not shown). The previous study also reflects weaker teleconnections between the tropical and extratropical regions related to the ENSO (Severijns and Hazeleger, 2010). NEMO (present model) and CLIO (previous model) are characterized by drastically modified ENSOrelated tropical variability in terms of variance and magnitude (Severijns and Hazeleger, 2010; Park et al., 2009). The NEMO ocean model used in the present study properly simulates the global oceanic features as it resolves convective and mesoscale processes in the mixed layer and thermohaline related to the ENSO.

\subsection{The astronomical forcing}

Turning to the impact of astronomical changes on global surface temperatures (AST minus CTR), warming is evident in the northeastern Pacific and Atlantic oceans (Fig. 2b). The orbital forcing during MIS31 reflects high obliquity and eccentricity, enhancing boreal summer insolation. Downward solar radiation differences at the top of the atmosphere between AST and CTR reach values of up to $50 \mathrm{~W} \mathrm{~m}^{2}$ at $60^{\circ} \mathrm{N}$ (not shown). In fact, increased heat in the oceanic surface layer during the summer months hinders the winter cooling and hampers sea ice cover over extratropical latitudes (Yin and Berger, 2012; Alexander et al., 1999). Thus, vigorous oceanic heat exchange in AST leads to higher near-surface air temperatures compared to the CTR run. Seasonal changes project onto annual conditions due to the remnant insolation effect that is stronger during the NH summertime (Yin and Berger, 2012).

Indeed, the $\mathrm{NH}(\mathrm{SH})$ warming (cooling) is primarily associated with intensified (weakened) summer insolation that is dominant in the polar and subtropical regions. In addition to reduced insolation in the $\mathrm{SH}$, stronger atmospheric circulation (southeast trade winds and westerlies) leads to lower surface temperatures due to stronger equatorial upwelling and modified Ekman dynamics (McCreary and Lu, 1994). The wind-evaporation-SST feedback also plays a role due to modification in the latent heat through evaporation (Wang et al., 1999).

Elsewhere, the atmospheric circulation and the heat exchanges associated with air-sea interactions determine annual mean conditions. The incorporation of the astronomical forcing also exhibits anomalous SSTs in such a way that the Atlantic Ocean anomalies resemble present day conditions under the positive phase of the Atlantic Multidecadal Oscillation (AMO; Delworth and Mann, 2000). SST anomalies in the North Pacific on the other hand, depict the warm phase of the Pacific Decadal Oscillation (PDO; Zhang et al., 1997). Therefore, these climate modes of variability (AMO and PDO) may be characteristic of a global climate governed by an excess of heat in the NH as occurred in the MIS31 interval. The 20th century climate, which experienced larger changes in $\mathrm{NH}$ temperatures compared to the $\mathrm{SH}$, also re- sulted from the influence of the AMO and PDO on temperature anomalies. In today's climate, the $\mathrm{NH}$ warming arises in part because of northward cross-equatorial OHT (Kang et al., 2015); however, the heat transport must be intensified under the external forcing characteristics of interglacial climates.

Table 1 and Fig. 2e demonstrate that the inclusion of orbital forcing leads to decreased (increased) sea ice area in the $\mathrm{NH}(\mathrm{SH})$ with statistically significant changes in the $\mathrm{NH}$. The SH experiences a greater change during JJA. However, Fig. 2e shows that when the annual average is assessed, most changes in the SH are significant and that the AST anomalous sea ice pattern opposes the TOPO response in the Weddell and Bellingshausen seas.

\subsection{The MIS31 climate}

The global climate response due to the combined effect of changing WAIS topography and astronomical forcing (MIS31 simulation) is primarily a result of changes in the latter forcing, as Fig. 2c shows a similar SST anomaly pattern as Fig. 2b. Nevertheless, the combined forcing appears not to be linear in the vicinity of Antarctica (Fig. S2 in the Supplement). Linearity is noted, however, by intensified warming in the Ross Sea as a result of warmer SSTs in TOPO and AST compared to the CTR climate. Nonlinearity is shown through reduced cooling in the Weddell Sea in the MIS31 simulation compared to the AST simulation (Fig. S2). This is related to the absence of the WAIS topography that reduces the strong cooling associated with changes in the astronomical forcing.

The anomalous SST patterns in the $\mathrm{NH}$ are also associated with modified air-sea coupling, in particular reduced Ekman drift and reduced evaporative cooling in concert with the MIS31 orbital forcing. Indeed, stronger midlatitude and polar westerlies over the Kuroshio-Oyashio region and weaker northeast trade winds over the central-eastern Pacific (not shown) result in higher SSTs and sea ice anomalies in the respective regions (Table 1, Fig. 2).

Modification of the WAIS topography is associated with changes in sea ice area, particularly in the Atlantic Ocean. Changes in the astronomical forcing, on the other hand, are more responsible for climate anomalies from a global perspective. Comparison between the MIS31 and the AST runs can be indirectly used to further identify the effect of the WAIS topography in the SH sea ice changes. Indeed, it is demonstrated that the substantial reduction in sea ice cover in the Ross Sea and to some extent changes in the Weddell Sea are substantially affected by the WAIS collapse (Fig. S1c). Specifically, the MIS31 simulation is warmer in the Weddell and Ross seas by up to $1.5^{\circ} \mathrm{C}$ with respect to AST, which is accompanied by an approximate $10 \%$ reduction in sea ice cover. In fact, the individual influence of the collapse of WAIS in MIS31 is more evident in the Bellingshausen Sea (Fig. 2e and f). In the NH, the removal of WAIS and orbital forcing act in opposite directions for sea ice changes. 
Table 2. SST paleoreconstruction and modeling intercomparison. Values in Table 2 have been extracted by drawing an orthogonal line to the time series with an intersection at approximately $1070 \mathrm{ka}$ between the dashed lines of Fig. 5 in Wet et al. (2016).

\begin{tabular}{lrrrl}
\hline Site (coordinates) & $\begin{array}{r}\text { Surf. temp. }\left({ }^{\circ} \mathrm{C}\right) \\
\text { reconstruction }\end{array}$ & $\begin{array}{r}\text { Surf. temp. }\left({ }^{\circ} \mathrm{C}\right) \\
\text { ICTP-CGCM }\end{array}$ & $\begin{array}{r}\text { Differences between } \\
\text { ICTP-CGCM and } \\
\text { reconstructions }\left({ }^{\circ} \mathrm{C}\right)\end{array}$ & Reference \\
\hline Lake E $\left(67^{\circ} \mathrm{N} 172^{\circ} \mathrm{E}\right)$ & 14.3 & 12.5 & -2.2 & Melles et al. (2012) \\
ODP $982\left(57^{\circ} \mathrm{N} 15^{\circ} \mathrm{W}\right)$ & 13.8 & 10.8 & -3.0 & Lawrence et al. (2009) \\
$\mathrm{DSDP} 607\left(41^{\circ} \mathrm{N} 33^{\circ} \mathrm{W}\right)$ & 17.5 & 16.9 & 0.6 & Raymo et al. (1996) \\
$306-\mathrm{U} 1313\left(41^{\circ} \mathrm{N} 32^{\circ} \mathrm{W}\right)$ & 18.0 & 16.9 & -1.1 & Naafs et al. (2013) \\
$1146\left(19^{\circ} \mathrm{N} 116^{\circ} \mathrm{E}\right)$ & 26.0 & 25.0 & -1.0 & Herbert et al. (2010a) \\
$722\left(16^{\circ} \mathrm{N} 59^{\circ} \mathrm{W}\right)$ & 27.0 & 28.0 & 1.0 & Herbert et al. (2010b) \\
$1143\left(9^{\circ} \mathrm{N} 113^{\circ} \mathrm{E}\right)$ & 28.3 & 27.5 & -0.8 & Li et al. (2011) \\
$871\left(5^{\circ} \mathrm{N} 172^{\circ} \mathrm{E}\right)$ & 29.3 & 28.9 & -0.4 & Dyez and Ravelo (2014) \\
$847\left(095^{\circ} \mathrm{W}\right)$ & 25.6 & 25.0 & -0.6 & Medina-Elizalde et al. (2008) \\
$849\left(0110^{\circ} \mathrm{W}\right)$ & 25.8 & 25.0 & -0.8 & McClymont and Rosell-Melé (2005) \\
$846\left(3^{\circ} \mathrm{S} 90^{\circ} \mathrm{W}\right)$ & 24.3 & 24.8 & 0.5 & Herbert et al. (2010c) \\
$\mathrm{MD}-06-301\left(23^{\circ} \mathrm{S} 166^{\circ} \mathrm{E}\right)$ & 25.0 & 23.9 & -1.1 & Russon et al. (2011) \\
$1087\left(31^{\circ} \mathrm{S} 15^{\circ} \mathrm{E}\right)$ & 18.0 & 17.7 & -0.3 & McClymont et al. (2005) \\
$1123\left(41^{\circ} \mathrm{S}, 171^{\circ} \mathrm{E}\right)$ & 16.0 & 16.8 & 0.8 & Crundwell et al. (2008) \\
$1090\left(42^{\circ} \mathrm{S} 8^{\circ} \mathrm{E}\right)$ & 11.5 & 9.8 & -1.7 & Martínez-Garcia et al. (2010) \\
\hline
\end{tabular}

The sensitivity experiments demonstrate that compared to CTR, warmer SSTs and reduced sea ice are only simulated in the Ross Sea region. This is in agreement with the Cape Roberts Project-1 results and data from the Antarctic Geological Drilling project (ANDRILL; Naish et al., 2009; Fig. 2). According to our results, outside of the Ross Sea, Antarctic sea ice during the MIS31 interval may have been more abundant compared to current conditions. In the $\mathrm{NH}$, however, sea ice cover is substantially reduced by up to $15 \%$ in DJF and by up to $50 \%$ in the AST and MIS31 runs in JJA (Table 1).

In order to provide a quantitative comparison between global temperature reconstructions and our modeling results, multiple proxies are used (Wet et al., 2016). Table 2 shows 15 sites distributed throughout both hemispheres (Fig. S3). Reconstructed temperature values in Table 2 have been extracted by drawing an orthogonal line to the time series with an intersection at approximately $1070 \mathrm{ka}$ in Fig. 5 by Wet et al. (2016). In the $\mathrm{NH}$, the model is colder than reconstructed temperatures $\left(2-3{ }^{\circ} \mathrm{C}\right)$ in extratropical latitudes, namely at the Lake E and ODP 982 sites (Table 2; Melles et al., 2012; Lawrence et al., 2009). These locations are dominated by extreme seasonality that may not be fully captured in the ICTP-CGCM. Over extratropical regions, heat advection embedded in storms has been pointed to as an important contributor for defining temperature and weather patterns over those regions (Lehmann and Coumou, 2015; Jost et al., 2005; Kageyama and Valdes, 2000). Storm tracks are tightly connected to the meridional thermal gradient, and over the continent more frequent cold spells in winter are related to decreased storm track activity (Lehmann and Coumou, 2015).

Lower-resolution models, such as the atmospheric component in the ICTP-CGCM, may limit the ability to repre- sent both the structure and intensity of the storms passing over East Asia and the North Atlantic. Subsequently, weaker storms may induce lower temperatures at the Lake $\mathrm{E}$ and ODP 982 sites. Elsewhere in the $\mathrm{NH}$, differences are less than $1{ }^{\circ} \mathrm{C}$ (Raymo et al., 1996; Li et al., 2011; Herbert et al., 2010a; Naafs et al., 2013).

In the equatorial regions, the model performs well compared to reconstructed temperatures with departures of up to $\pm 1{ }^{\circ} \mathrm{C}$ (Herbert et al., 2010b; Li et al., 2011; Dyez and Ravelo, 2014; Medina-Elizalde et al., 2008; McClymont and Rosell-Melé, 2005; Herbert et al., 2010c; Russon et al., 2011). Comparing ODP sites $849,847,846$, and 871 in the equatorial Pacific (Table 2), the east-west SST gradient may be identified as supported by changes in the zonal circulation. Indeed, the MIS31 climate experiences weaker trade winds, which is consistent with Martínez-Garcia et al. (2010). The ODP sites in the SH also corroborate previous results showing small differences between the model and reconstructions (Table 2; Scherer et al., 2008; Voelker et al., 2015; Naish et al., 2009; Russon et al., 2011; McClymont et al., 2005; Crundwell et al., 2008; Martínez-Garcia et al., 2010).

\subsection{Changes in $\mathrm{MOC}$ and $\mathrm{OHT}$}

There is particular interest in evaluating changes to the MOC associated with warming and/or freshening of the NH highlatitude surface waters due to natural variability and/or including anthropogenic-induced global warming (Rahmstorf et al., 2015). The AMOC is a key element of the climate system because it carries a substantial amount of heat poleward, and on long timescales AMOC plays an important role in coupling the SH and NH (Broecker, 1998). 
The ICTP-CGCM AMOC exhibits values that closely match observations (Kanzow et al., 2010; Ferrari and Ferreira, 2011; Talley et al., 2003) and higher-resolution models (Stepanov and Haines, 2014). Consequently, a fair representation of the AMOC should lead to proper OHT estimates under present day conditions because the majority of the OHT is driven by the AMOC. Moreover, the resolution of ICTPCGCM across the tropics is sufficient enough to capture the majority of the OHT for the globe.

The Antarctic bottom water (AABW) is closely related to sea ice processes that involve brine release due to sea ice formation and winds (Stössel et al., 1998). Despite limitations in reproducing the sea ice seasonal features in the ICTPCGCM, simulated deep water formation in the SH occurs in both the Atlantic and Pacific oceans (Figs. 3-4).

The AABW represented by our CTR run in the Atlantic attains values of about $5 \mathrm{~Sv}\left(10^{6} \mathrm{~m}^{3} \mathrm{~s}^{-1}\right)$, which is comparable to $8 \mathrm{~Sv}$ based on absolute geostrophic velocity from hydrographic data (Talley et al., 2003) and from climatological Ekman transports. At $25^{\circ} \mathrm{S}$, the ICTP-CGCM delivers AABW in the Pacific Ocean up to $10 \mathrm{~Sv}$, which is also in line with Talley et al. (2003), and 6-8 Sv at $10^{\circ} \mathrm{N}$ matched values found by Wijffels et al. (1996).

Figure $3 \mathrm{a}$ and $\mathrm{d}$ show that compared to data-based estimates (Ganachaud and Wunsch, 2000), the ICTP-CGCM properly reproduces the magnitude of the North Atlantic Deep Water (NADW; $15 \pm 2 \mathrm{~Sv}$ ) at $2^{\circ} \mathrm{N}$. The main sites of the NADW formation, namely the Greenland, Iceland, and Norwegian (GIN) seas and the Labrador Sea (Wood et al., 1999), are also properly located as shown by analyses of the density contribution (Fig. 3a). Thermal changes dominate the NADW formation in comparison to the haline contribution. Indeed, a much colder extratropical atmosphere over the warmer ocean increases the vertical air-sea temperature contrast and consequently the ocean-atmosphere heat exchange (Schmitt et al., 1989; Speer and Tziperman, 1992). This leads to stronger convective mixing (Fig. 3a).

The modification of the WAIS results in a slightly reduced (but statistically significant) rate of formation of the NADW compared to the CTR (Fig. 3e). The weakening of the NADW in the TOPO simulation is associated with a reduction in the Labrador Sea surface salinity. Moreover, reduced heat exchange between the ocean and the atmosphere in the GIN seas due to an increase in sea ice plays a role (Table 1; Fig. 2d), thereby reducing convective mixing (Fig. 3b).

Changes in the topography of the WAIS (Figs. 2 and 3) are stronger in the SH extratropics, and therefore AST and MIS31 elsewhere show a similar anomalous pattern in respect to the CTR simulation. Thus, we choose to show only results for MIS31. Figure 3c shows that despite reduced sea ice compared to CTR, there is thermally increased surface water density at the main sites of deep water formation in the MIS31 simulation, particularly in the Labrador and GIN seas (show as positive labels in Fig. $3 \mathrm{c}$ and $\mathrm{f}$ ). Thus, the NADW in this experiment is deeper and more intense compared to CTR.

As shown by the thermal contribution, the acceleration of the MOC during the MIS31 simulation compared to the CTR simulation (Fig. 3f) is also a response to intensified westerly atmospheric flow across the northern North Atlantic (not shown). This leads to strong convective mixing. It can also be argued that less intrusion of the Antarctic water in the North Atlantic above $4000 \mathrm{~m}$ contributes to increased vertical instability favoring oceanic convection (Haupt and Seidov, 2012). This is opposite to findings concerning the Last Glacial Maximum (McManus et al., 2004; Peltier and Solheim, 2004), which assume that a large intrusion of Antarctic water into the North Atlantic restricts most of the NADW to a shallower part of the ocean (Ballarotta et al., 2014).

The inclusion of MIS31 boundary conditions further affects the position of the main sites of deep water formation. Figure $3 \mathrm{c}$ shows that the convection sites in MIS31 have been shifted poleward compared to CTR. The Labrador and GIN seas concentrate a large amount of deep water formation. This occurs as a result of intensified surface wind field near $60^{\circ} \mathrm{N}$ (not shown) and subsequently leads to a strengthening of the subtropical gyre northward of its position in the CTR run. The North Atlantic also experiences increased salinity in the MIS31 simulation compared to CTR, which is advected into the Labrador and GIN seas (Fig. 4d). An intensified MOC during MIS31 and associated OHT have also been suggested by paleoreconstructions (Scherer et al., 2008) and have been claimed to prevent $\mathrm{NH}$ cooling during the MIS11 interval (Dickson et al., 2009). Figure 4a shows that our modeled OHT is in the range of global observations based on (Ganachaud and Wunsch, 2003, 2000). It should be noted as well that these observations exhibit large uncertainties in magnitude, especially across the SH tropical region. These errors can be as large as $0.55 \mathrm{PW}$ (petawatt) at $4.5^{\circ} \mathrm{S}$ and $0.6 \mathrm{PW}$ at $1^{\circ} \mathrm{S}$ in the Atlantic, which represent in some cases more than $60 \%$ of the total estimated OHT.

Insofar as the ICTP-CGCM is concerned (Fig. 4a), it underestimates the $\mathrm{OHT}$ in the $\mathrm{NH}$ due to its limitations in the Atlantic Ocean while the OHT in the Pacific is in the range or interval of values proposed by Ganachaud and Wunsch (2003, 2000). Between 20 and $30^{\circ} \mathrm{N}$, where observations exhibit smaller errors, the model slightly overestimates the OHT in the Indo-Pacific region and underestimates in the Atlantic Ocean. These differences may be responsible for lower modeled SSTs over the extratropical region of the North Atlantic compared to the ODP site 982. The OHT in the TOPO changes slightly compared to the CTR. However, in the AST and MIS31 simulations, a clear pattern of increased astronomically driven northward OHT is present (Fig. 4a). In the midlatitudes, an intensified atmospheric westerly flow in the vicinity of the American continent is simulated in the AST and MIS31 experiments. This contributes to an enhanced OHT via the transport of warmer subtropical water to midlatitudes (Fig. 4a). As previously mentioned, southward trans- 

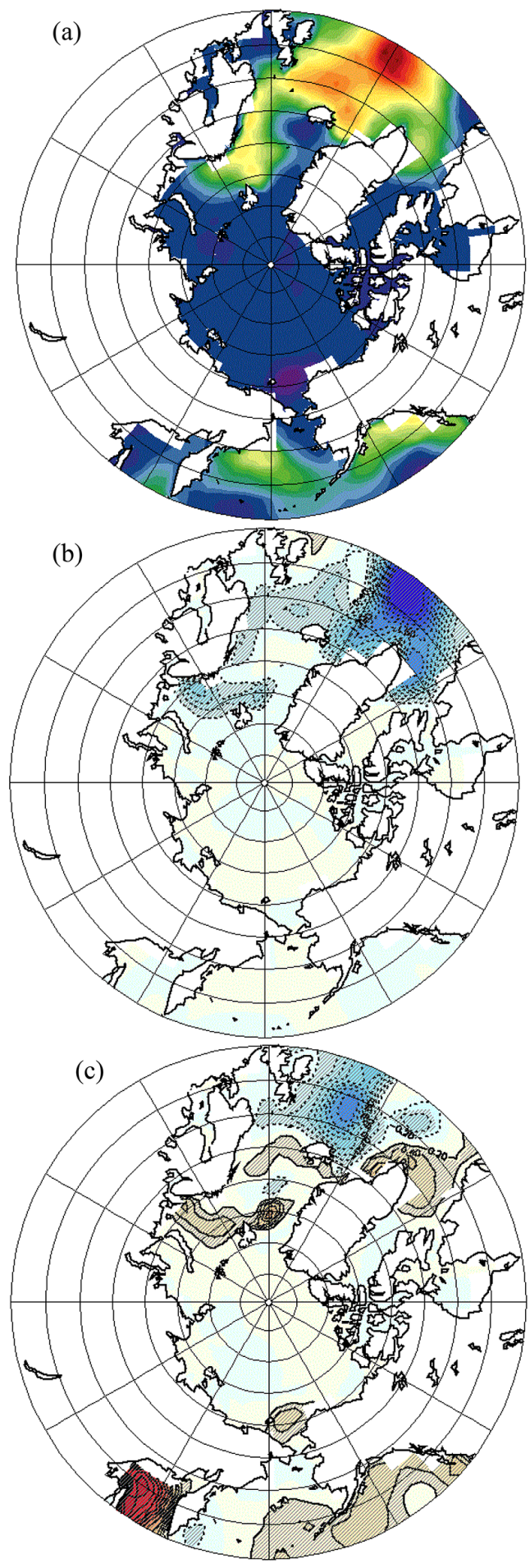

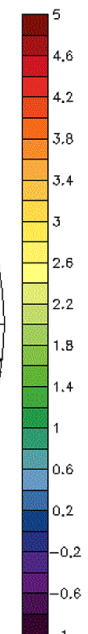

(d)

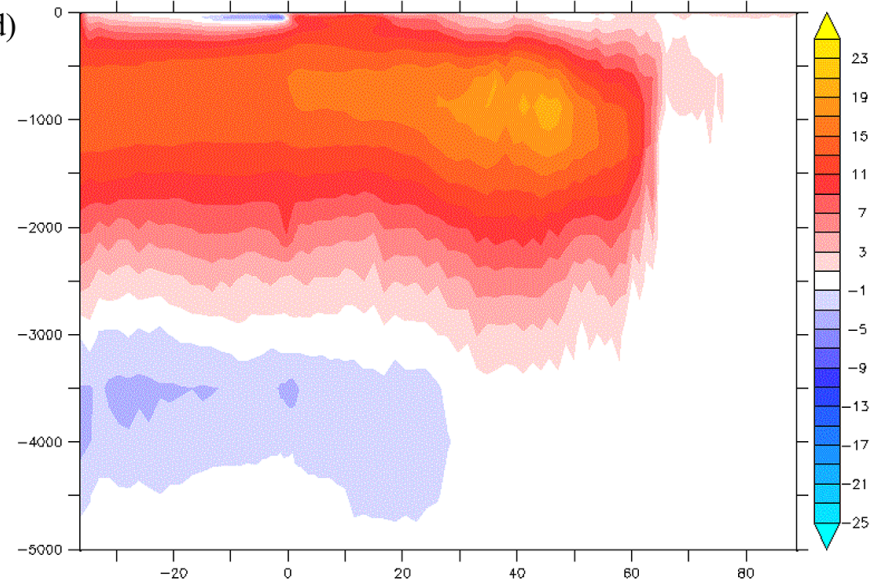

(e)

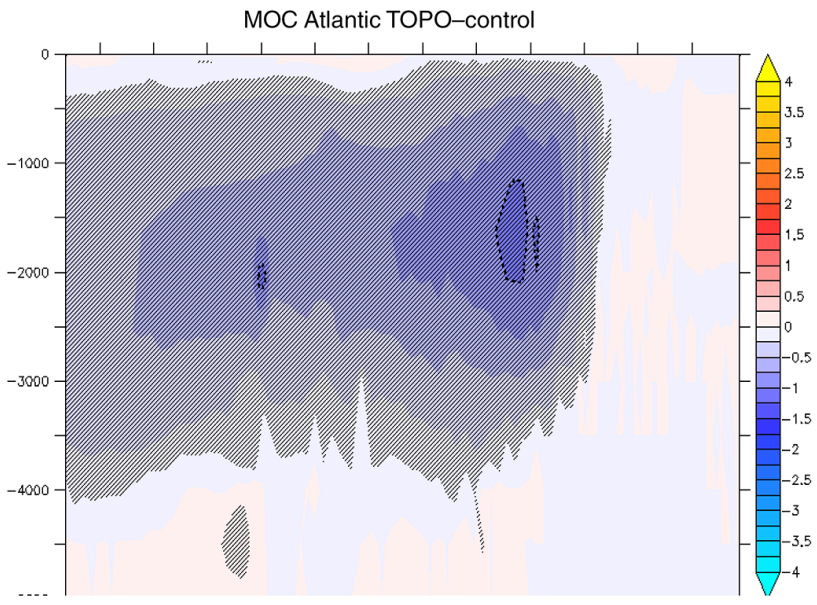

(f)

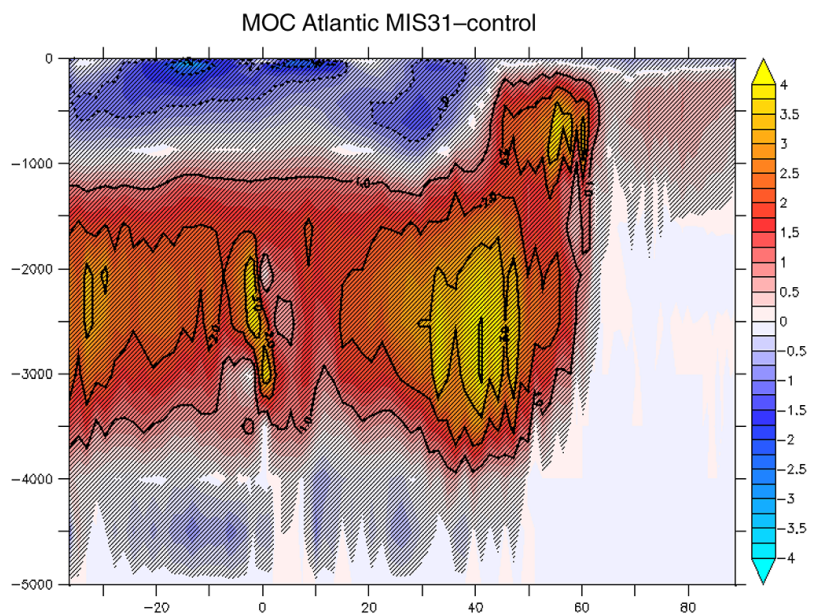

Figure 3. Density flux for CTR $\left(\mathbf{a}, 10^{6} \mathrm{~kg} \mathrm{~m}^{-2} \mathrm{~s}^{-1}\right)$ and differences between TOPO-CTR (b) and (c) MIS31-CTR. (d) MOC (Sv) in the CTR and differences between the (e) TOPO-CTR and (f) MIS31-CTR. The hatched areas are significant at $95 \%$ based on $t$-test statistics. 
(a)

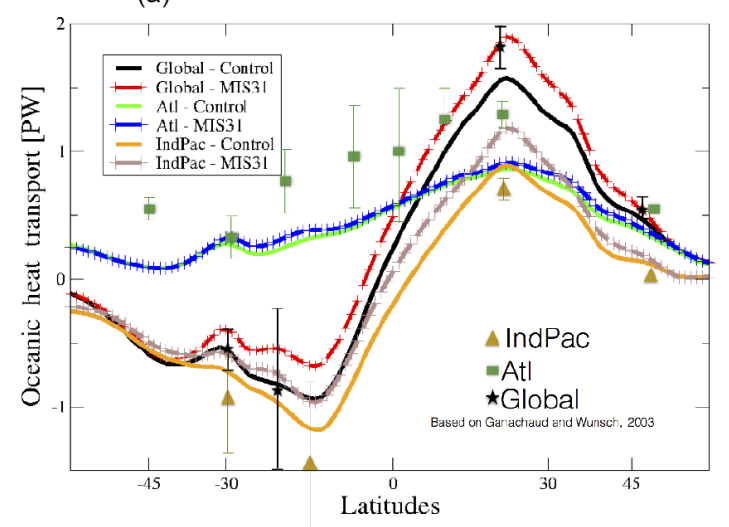

(b)

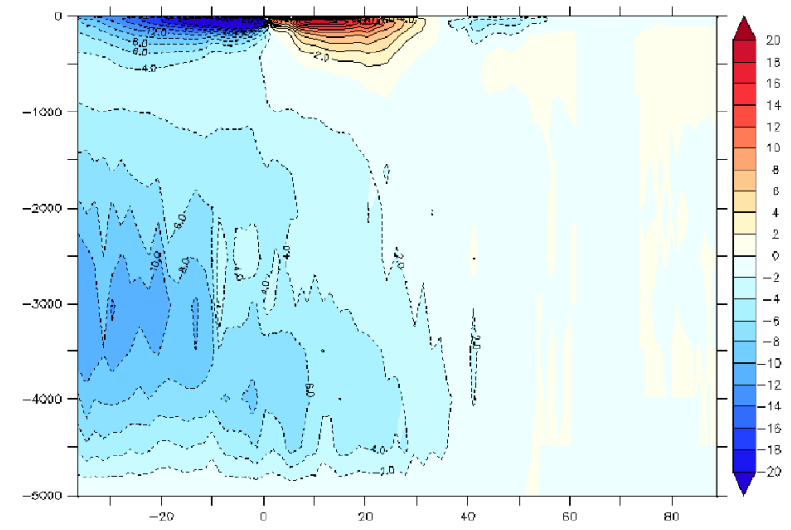

(c)

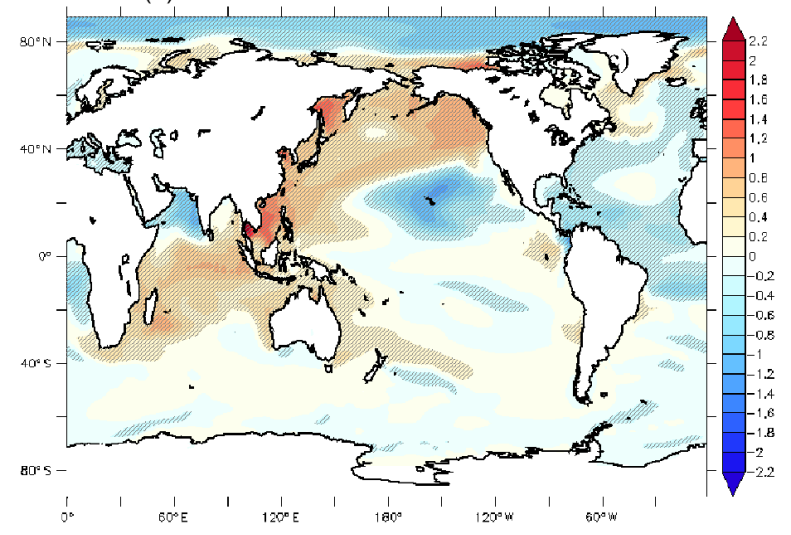

(d)

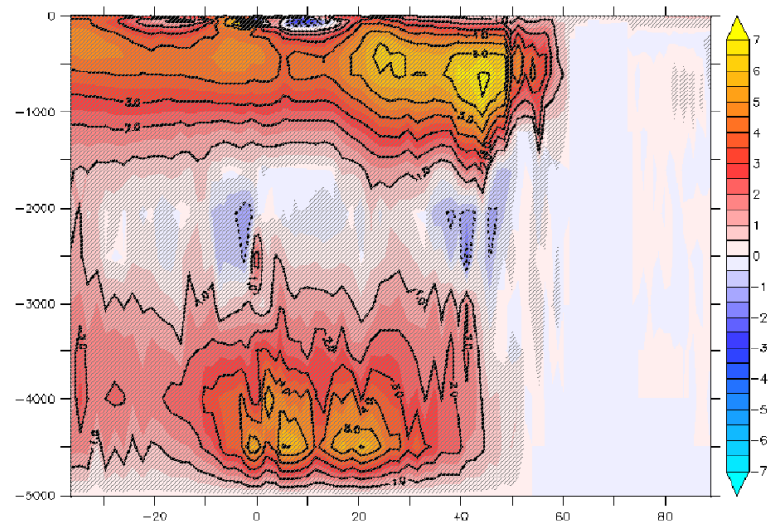

Figure 4. (a) Time-averaged OHT (PW) for CTR (solid line) and MIS31 (dashed-crossed line). Stars, squares, and triangles show estimates based on Ganachaud and Wunsch (2003). (b) Pacific Meridional Overturning Circulation (PMOC) in the CTR. (c) Sea surface salinity differences between MIS31 and CTR. (d) Differences between the MIS31 and CTR PMOC. The hatched regions in panels (c) and (d) are significant at $95 \%$ based on $t$-test statistics.

port between 0 and $1000 \mathrm{~m}$ in the NH midlatitudes is reduced (Fig. 3f).

Interestingly, Fig. 4a also shows an essential contribution to global OHT anomalies from the Indo-Pacific since little difference in OHT is found across the Atlantic in the MIS31 simulation compared to CTR. This finding is in line with previous results demonstrating that increased OHT into the Arctic Ocean results in better correspondence between modeling results and the Lake E reconstruction (Coletti et al., 2015). Enhanced OHT during MIS31 is also supported by the ODP sites 846 (Herbert et al., 2010c) and 849 (McClymont and Rosell-Melé, 2005).

In order to investigate potential causes for the increased OHT in the MIS31 climate, Fig. 4 shows the sea surface salinity (SSS) and the vertical oceanic circulation pattern in the Pacific Ocean. Under CTR conditions, little North Pacific deep water forms (Fig. 4b). However, changes in the astronomical forcing induce modifications in the surface water density.
The density contribution (Fig. 3c) shows that the incorporation of the astronomical forcing leads to an increase in water density in the North Pacific and a simultaneous increase in SSS (see Fig. 4c). Moreover, the initial acceleration of the subtropical gyre associated with modified midlatitude westerlies and the associated heat loss from the ocean to the atmosphere northward of $40^{\circ} \mathrm{N}$ also contribute to an increase in the surface density (Fig. 3c). Subsequently, this leads to the formation of the southward branch of the Pacific Meridional Overturning Circulation (PMOC; Fig. 4d).

Reduction in sea ice cover reduces the density changes in the interface between sea ice and water, but this contribution to the PMOC weakening is marginal and confined to the Arctic region. Additional contribution to the PMOC is provided by increased $E-P$ flux in the AST and MIS31 runs compared to the CTR, which further increases the SSS in the North Pacific (Fig. 4b). Figure S5 summarizes the airsea mechanisms involved in the PMOC formation rate. Evaluating the individual contributions of the wind-driven and 
thermohaline circulation to North Pacific OHT across $26^{\circ} \mathrm{N}$ shows that under CTR conditions from the surface to $300 \mathrm{~m}$ of depth, the wind-driven component contributes up to $58 \%$ $(0.55 \mathrm{PW})$ of the total OHT (not shown). These values are similar to previous estimates based on observations (Talley, 2003). This demonstrates that in the subtropics and midlatitudes, most of the OHT is the result of the North Pacific gyre. An additional $42 \%(0.40 \mathrm{PW})$ of OHT occurs in the 300-1200 m layer.

For the MIS31 climate, the OHT associated with the winddriven circulation $(0-300 \mathrm{~m})$ at $26^{\circ} \mathrm{N}$ is less than that of the CTR simulation and represents $44 \%$ of the total $(55 \%$ in the CTR). This indicates that at this latitude, an important contribution to OHT is related to the thermohaline circulation below the Ekman layer. Compared to the CTR simulation, this represents an increase of $16 \%$, from $40 \%$ in the CTR to $56 \%$ in the MIS31. It should to be mentioned, however, that separating the thermohaline and wind-driven contributions should be interpreted carefully, as the wind-driven density transport partly drives the thermohaline circulation (Talley, 2003).

As shown by vertically integrating the zonal and meridional OHT at the basin scale, the contribution of the gyre circulation is dominant, particularly between 30 and $45^{\circ} \mathrm{N}$ (Fig. S4). Under MIS31 conditions, zonally induced OHT is even stronger (Fig. S2b), but northward of $45^{\circ} \mathrm{N}$ the role of the meridional contribution should be taken into account (Fig. S2d). Hence, the evaluation of the OHT in a single longitudinal belt does not fully describe the OHT picture insofar as the characteristics of large-scale domains are needed.

\section{Summary and concluding remarks}

Based on coupled climate simulations performed under present day and boundary conditions representative of Marine Isotope Stage 31 (MIS31), our analyses provide evidence that under MIS31 climate conditions there was a remarkable reduction in sea ice distribution across the $\mathrm{NH}$ due to the astronomical configuration of that epoch. This contrasts with increases in sea ice area across the $\mathrm{SH}$. The climate response to collapsing the WAIS is prominent in the vicinity of the Antarctic continent, whereas the effect of modification in the Earth orbital configuration extends worldwide.

It has furthermore been demonstrated that the MIS31 interglacial experienced significant changes in the Meridional Overturning Circulation (MOC). In the Atlantic, increases in the MOC are related to an intensified westerly atmospheric flow in the northern North Atlantic, leading to strong convective mixing. The main convection sites in MIS31 have also been shifted poleward compared to the control simulation (CTR) in concert with changes in the position of the meridional thermal gradient.
Increased water density due to surface salinity changes and the acceleration of the subtropical gyre associated with modified midlatitude westerlies in the MIS31 climate are responsible for modifying the convection in the North Pacific, resulting in the existence of a southward meridional thermohaline flow (PMOC). We suggest that this feature and associated $\mathrm{OHT}$ (Fig. 4a) play key roles in the $\mathrm{NH}$ warming during the MIS31 interval, as suggested by paleoreconstructions.

These modeling results have enormous implications for paleoreconstructions of the MIS31 climate that mostly assume overall ice-free conditions in the vicinity of the Antarctic continent. Since these reconstructions may depict dominant signals in a particular time interval and locale, they cannot be assumed to geographically represent large-scale domains. Therefore, their ability to reproduce long-term environmental conditions should be considered with care. Finally, it is important to emphasize that understanding past interglacial intervals that are characterized by a depleted WAIS can shed light on the potential effects of increasing atmospheric $\mathrm{CO}_{2}$, as the stability of the WAIS will be a key climate factor in decades to come (DeConto and Pollard, 2016; Nicolas et al., 2017).

Data availability. The model simulation data set may be accessed by request to the author.

\section{The Supplement related to this article is available online at https://doi.org/10.5194/cp-13-1081-2017-supplement.}

Author contributions. FJ designed the study, wrote large portions of the paper, and performed data processing and plotting. DL and FK performed all model simulations. All authors substantially contributed to the interpretation of the results.

Competing interests. The authors declare that they have no conflict of interest.

Acknowledgements. This work was supported by the Brazilian National Research Council projects 232718/2014-8 and 407681/2013-2. The first author also thanks the Byrd Polar and Climate Research Center (BPCRC) for providing the necessary infrastructure. This is the BPCRC contribution number C-1569.

NOAA OI Sea Surface Temperature V2 and ICOADS data are provided by the NOAA/OAR/ESRL PSD in Boulder, Colorado, USA from their website at http://www.esrl.noaa.gov/psd/. ERAI $E-P$ flux was provided by the National Center for Atmospheric Research staff in "The Climate Data Guide: ERA-Interim: derived components" retrieved from https://climatedataguide.ucar. edu/climate-data/era-interim-derived-components, last modified 2 January 2014. 
Edited by: Erin McClymont

Reviewed by: two anonymous referee

\section{References}

Aiken, C. M. M. H. E.: Sensitivity of the present-day climate to freshwater forcing associated with Antarctic sea ice loss, J. Climate, 21, 3936-3946, https://doi.org/10.1175/2007JCLI1901.1, 2008.

Alexander, M. A., Deser, C., and Timlin, M. S.: The reemergence of SST anomalies in the North Pacific Ocean, J. Climate, 12, 24192433, 1999.

Ballarotta, M., Falahat, S., Brodeau, L., and Döös, K.: On the glacial and interglacial thermohaline circulation and the associated transports of heat and freshwater, Ocean Sci., 10, 907-921, https://doi.org/10.5194/os-10-907-2014, 2014.

Berger, A.: Long-term variations of daily insolation and Quaternary climatic changes, J. Atmos. Sci., 35, 2362-2367, https://doi.org/10.1175/15200469(1978)035<2362:LTVODI>2.0.CO;2, 1978.

Bindoff, N. L., Stott, P. A., AchutaRao, K. M., Allen, M. R., Gillett, N., Gutzler, D., Hansingo, K., Hegerl, G., Hu, Y., Jain, S., Mokhov, I. I., Overland, J., Perlwitz, J., Sebbari, R., and Zhang, X.: Detection and Attribution of Climate Change: from Global to Regional Supplementary Material, in: Climate Change 2013: The Physical Science Basis. Contribution of Working Group I to the Fifth Assessment Report of the Intergovernmental Panel on Climate Change, edited by: Stocker, T. F., Qin, D., Plattner, G.-K., Tignor, M., Allen, S. K., Boschung, J., Nauels, A., Xia, Y., Bex, V., and Midgley, P. M., Cambridge University Press, Cambridge, UK, 2013.

Broecker, W.: Paleocean circulation during the last deglaciation. A bipolar seesaw?, Paleoceanography, 13, 119-121, 1998.

Bush, A. B. G. and Philander, S. G. H.: The Role of OceanAtmosphere Interactions in Tropical Cooling During the Last Glacial Maximum, Science, 279, 1341-1344, 1998.

Coletti, A. J., DeConto, R. M., Brigham-Grette, J., and Melles, M.: A GCM comparison of Pleistocene super-interglacial periods in relation to Lake El'gygytgyn, NE Arctic Russia, Clim. Past, 11, 979-989, https://doi.org/10.5194/cp-11-979-2015, 2015.

Comeau, D., Kurtze, D. A., and Restrepo, J. M.: A conceptual model of oceanic heat transport in the Snowball Earth scenario, Earth Syst. Dynam., 7, 937-951, https://doi.org/10.5194/esd-7937-2016, 2016.

Crundwell, M., Scott, G., Naish, T., and Carter, L.: Glacialinterglacial ocean climate variability from planktonic foraminifera during the Mid-Pleistocene transition in the temperate Southwest Pacific, ODP Site 1123, Palaeogeogr. Palaeocl., 260, 202-229, 2008.

Dahl-Jensen, D., Albert, M., Aldahan, A., Azuma, N., BalslevClausen, D., Baumgartner, M., Berggren, A.-M., Bigler, M., Binder, T., Blunier, T., Bourgeois, J. C., Brook, E. J., Buchardt, S. L., Buizert, C., Capron, E., Chappellaz, J., Chung, J., Clausen, H. B., Cvijanovic, I., Davies, S. M., Ditlevsen, P., Eicher, O., Fischer, H., Fisher, D. A., Fleet, L. G., Gfeller, G., Gkinis, V., Gogineni, S., Goto-Azuma, K., Grinsted, A., Gudlaugsdottir, H., Guillevic, M., Hansen, S. B., Hansson, M., Hirabayashi, M., Hong, S., Hur, S. D., Huybrechts, P., Hvidberg, C. S., Iizuka,
Y., Jenk, T., Johnsen, S. J., Jones, T. R., Jouzel, J., Karlsson, N. B., Kawamura, K., Keegan, K., Kettner, E., Kipfstuhl, S., Kjær, H. A., Koutnik, M., Kuramoto, T., Köhler, P., Laepple, T., Landais, A., Langen, P. L., Larsen, L. B., Leuenberger, D., Leuenberger, M., Leuschen, C., Li, J., Lipenkov, V., Martinerie, P., Maselli, O. J., Masson-Delmotte, V., McConnell, J. R., Miller, H., Mini, O., Miyamoto, A., Montagnat-Rentier, M., Mulvaney, R., Muscheler, R., Orsi, A. J., Paden, J., Panton, C., Pattyn, F., Petit, J.-R., Pol, K., Popp, T., Possnert, G., Prié, F., Prokopiou, M., Quiquet, A., Rasmussen, S. O., Raynaud, D., Ren, J., Reutenauer, C., Ritz, C., Röckmann, T., Rosen, J. L., Rubino, M., Rybak, O., Samyn, D., Sapart, C. J., Schilt, A., Schmidt, A. M. Z., Schwander, J., Schüpbach, S., Seierstad, I., Severinghaus, J. P., Sheldon, S., Simonsen, S. B., Sjolte, J., Solgaard, A. M., Sowers, T., Sperlich, P., Steen-Larsen, H. C., Steffen, K., Steffensen, J. P., Steinhage, D., Stocker, T. F., Stowasser, C., Sturevik, A. S., Sturges, W. T., Sveinbjörnsdottir, A., Svensson, A., Tison, J.-L., Uetake, J., Vallelonga, P., van de Wal, R. S. W., van der Wel, G., Vaughn, B. H., Vinther, B., Waddington, E., Wegner, A., Weikusat, I., White, J. W. C., Wilhelms, F., Winstrup, M., Witrant, E., Wolff, E. W., Xiao, C., and Zheng, J.: Eemian interglacial reconstructed from a Greenland folded ice core, Nature, 493, 489-494, https://doi.org/10.1038/nature11789, 2013.

Dawson, A., Matthews, A. J., Stevens, D. P., Roberts, M. J., and Vidale, P. L.: Importance of oceanic resolution and mean state on the extra-tropical response to El Nino in a matrix of coupled models, Clim. Dynam., 41, 1439-1452, 2013.

DeConto, R. M. and Pollard, D.: Contribution of Antarctica to past and future sea-level rise, Nature, 531, 591-597, 2016.

DeConto, R. M., Pollard, D., and Kowalewski, D.: Modeling Antarctic ice sheet and climate variations during Marine Isotope Stage 31, Global Planet. Change, 88-89, 45-52, https://doi.org/10.1016/j.gloplacha.2012.03.003, 2012.

Dee, D. P., Uppala, S. M., Simmons, A. J., Berrisford, P., Poli, P., Kobayashi, S., Andrae, U., Balmaseda, M. A., Balsamo, G., Bauer, P., Bechtold, P., Beljaars, A. C. M., van de Berg, L., Bidlot, J., Bormann, N., Delsol, C., Dragani, R., Fuentes, M., Geer, A. J., Haimberger, L., Healy, S. B., Hersbach, H., Hólm, E. V., Isaksen, L., Kallberg, P., Ki ohler, M., Matricardi, M., McNally, A. P., Monge-Sanz, B. M., Morcrette, J.-J., Park, B.-K., Peubey, C., de Rosnay, P., Tavolato, C., Thépaut, J.-N., and Vitart, F.: The ERA-Interim reanalysis: configuration and performance of the data assimilation system, Q. J. Roy. Meteor. Soc., 137, 553-597, https://doi.org/10.1002/qj.828, 2011.

Delworth, T. L. and Mann, M. E.: Observed and simulated multidecadal variability in the Northern Hemisphere, Clim. Dynam., 16, 661-676, https://doi.org/10.1007/s003820000075, 2000.

Dickson, A. J., Beer, C. J., Dempsey, C., Maslin, M. A., Bendle, J. A., McClymont, E. L., and Pancost, R. D.: Oceanic forcing of the Marine Isotope Stage 11 interglacial, Nat. Geosci., 2, 428433, https://doi.org/10.1038/ngeo527, 2009.

Dyez, K. A. and Ravelo, A. C.: Dynamical changes in the tropical Pacific warm pool and zonal SST gradient during the Pleistocene, Geophys. Res. Lett., 41, 7626-7633, https://doi.org/10.1002/2014GL061639, 2014.

Erb, M., Broccoli, A., Graham, N., Clement, A., Wittenberg, A., and Vecchi, G.: Response of the equatorial pacific seasonal cycle to orbital forcing, J. Climate, 28, 9258-9276, https://doi.org/10.1175/JCLI-D-15-0242.1, 2015. 
Ferrari, R. and Ferreira, D.: What processes drive the ocean heat transport?, Ocean Model., 38, 171-186, https://doi.org/10.1016/j.ocemod.2011.02.013, 2011.

Ganachaud, A. and Wunsch, C.: Improved estimates of global ocean circulation, heat transport and mixing from hydrographic data, Nature, 408, 453-457, 2000.

Ganachaud, A. and Wunsch, C.: Large-scale ocean heat and freshwater transports during the World Ocean Circulation Experiment, J. Climate, 16, 696-705, 2003.

Griffies, S. M., Biastoch, A., Böning, C., Bryan, F., Danabasoglu, G., Chassignet, E. P., England, M. H., Gerdes, R., Haak, H., Hallberg, R. W., Hazeleger, W., Jungclaus, J., Large, W. G., Madec, G., Pirani, A., Samuels, B. L., Scheinert, M., Sen Gupta, A., Severijns, C. A., Simmons, H. L., Treguier, A. M., Winton, M., Yeager, S., and Yin, J.: Coordinated oceanice reference experiments (COREs), Ocean Model., 26, 1-46, https://doi.org/10.1016/j.ocemod.2008.08.007, 2009.

Haupt, B. and Seidov, D.: Modeling geologically abrupt climate changes in the Miocene: Potential effects of highlatitudinal salinity changes, Natural Science, 4, 149-158, https://doi.org/10.4236/ns.2012.43022, 2012.

Herbert, T. D., Peterson, L. C., Lawrence, K. T., and Liu, Z.: Tropical ocean temperatures over the past 3.5 million years, Science, 328, 1530-1534, 2010a.

Herbert, T. D., Peterson, L. C., Lawrence, K. T., and Liu, Z.: Tropical ocean temperatures over the past 3.5 million years, Science, 328, 1530-1534, 2010b.

Herbert, T. D., Peterson, L. C., Lawrence, K. T., and Liu, Z.: Tropical ocean temperatures over the past 3.5 million years, Science, $328,1530-1534,2010 \mathrm{c}$

Honisch, B., Hemming, N. G., Archer, D., Siddall, M., and McManus, J. F.: Atmospheric Carbon Dioxide Concentration Across the Mid-Pleistocene Transition, Sciene, 324, 1551-1554, https://doi.org/10.1126/science.1171477, 2009.

Jia-Jin, L.: The double-itcz problem in ipcc ar4 coupled gcms: ocean-atmosphere feedback analysis, J. Climate, 20, 4497-4525, https://doi.org/10.1175/JCLI4272.1, 2007.

Jost, A., Lunt, D., Kageyama, M., Abe-Ouchi, A., Peyron, O., Valdes, P., and Ramstein, G.: High-resolution simulations of the Last Glacial Maximum climate over Europe: a solution to discrepancies with continental palaeoclimatic reconstructions?, Clim. Dynam., 24, 557-590, 2005.

Justino, F., Silva, A. S., Pereira, M. P., Stordal, F., Lindemann, D., and Kucharski, F.: The Large-Scale Climate in Response to the Retreat of the West Antarctic Ice Sheet, J. Climate, 28, 637-650, https://doi.org/10.1175/JCLI-D-14-00284.1, 2015.

Kageyama, M. and Valdes, P.: Impact of the North American icesheet orography on the Last Glacial Maximum eddies and snowfall, Geophys. Res. Lett., 27, 1515-1518, 2000.

Kang, S. M., Seager, R., Frierson, D. M., and Liu, X.: Croll revisited: Why is the Northern Hemisphere warmer than the Southern Hemisphere?, Clim. Dynam., 44, 1457-1472, 2015.

Kanzow, T., Cunningham, S., Johns, W. E., Hirschi, J. J., Marotzke, J., Baringer, M., Meinen, C., Chidichimo, M., Atkinson, C., Beal, L., Bryden, H. L., and Collins, J.: Seasonal variability of the Atlantic meridional overturning circulation at $26.5^{\circ} \mathrm{N}$, J. Climate, 23, 5678-5698, 2010.
Knorr, G. and Lohmann, G.: Climate warming during Antarctic ice sheet expansion at the Middle Miocene transition, Nat. Geosci., 7, 376-381, https://doi.org/10.1038/ngeo2119, 2014.

Knutti, R., Flueckiger, J., Stocker, T., and Timmermann, A.: Strong hemispheric coupling of glacial climate through continental freshwater discharge and ocean circulation, Nature, 430, 851856, 2004.

Kucharski, F., Molteni, F., and Bracco, A.: Decadal interactions between the western tropical Pacific and the North Atlantic Oscillation, Clim. Dynam., 26, 79-91, 2006.

Kucharski, F., Ikram, F., Molteni, F., Farneti, R., Kang, I., No, H., King, M., Giuliani, G., and Mogensen, K.: Atlantic forcing of Pacific decadal variability, Clim. Dynam., 7, 1169-1188, 2015.

Lawrence, K. T., Herbert, T. D., Brown, C. M., Raymo, M. E., and Haywood, A. M.: High-amplitude variations in North Atlantic sea surface temperature during the early Pliocene warm period, Paleoceanography, 24, pA2218, https://doi.org/10.1029/2008PA001669, 2009.

Lehmann, J. and Coumou, D.: The influence of mid-latitude storm tracks on hot, cold, dry and wet extremes, Scientific reports, 5, 17491, https://doi.org/10.1038/srep17491, 2015.

Li, L., Li, Q., Tian, J., Wang, P., Wang, H., and Liu, Z.: A 4-Ma record of thermal evolution in the tropical western Pacific and its implications on climate change, Earth Planet. Sc. Lett., 309, 10-20, https://doi.org/10.1016/j.epsl.2011.04.016, 2011.

Lisiecki, L. E. and Raymo, M. E.: A Pliocene-Pleistocene stack of 57 globally distributed benthic $\delta^{18} \mathrm{O}$ records, Paleoceanography, 20, pA1003, https://doi.org/10.1029/2004PA001071, 2005.

Loulergue, L., Schilt, A., Spahni, R., Masson-Delmotte, V., Blunier, T., Lemieux, B., Barnola, J.-M., Raynaud, D., Stocker, T. F., and Chappellaz, J.: Orbital and millennial-scale features of atmospheric $\mathrm{CH}_{4}$ over the past 800,000 years, Nature, 453, 383-386, 2008.

Lunt, D. J., Huber, M., Anagnostou, E., Baatsen, M. L. J., Caballero, R., DeConto, R., Dijkstra, H. A., Donnadieu, Y., Evans, D., Feng, R., Foster, G. L., Gasson, E., von der Heydt, A. S., Hollis, C. J., Inglis, G. N., Jones, S. M., Kiehl, J., Kirtland Turner, S., Korty, R. L., Kozdon, R., Krishnan, S., Ladant, J.-B., Langebroek, P., Lear, C. H., LeGrande, A. N., Littler, K., Markwick, P., Otto-Bliesner, B., Pearson, P., Poulsen, C. J., Salzmann, U., Shields, C., Snell, K., Stärz, M., Super, J., Tabor, C., Tierney, J. E., Tourte, G. J. L., Tripati, A., Upchurch, G. R., Wade, B. S., Wing, S. L., Winguth, A. M. E., Wright, N. M., Zachos, J. C., and Zeebe, R. E.: The DeepMIP contribution to PMIP4: experimental design for model simulations of the EECO, PETM, and pre-PETM (version 1.0), Geosci. Model Dev., 10, 889-901, https://doi.org/10.5194/gmd10-889-2017, 2017.

Madec, G.: NEMO: the OPA ocean engine, Note du Pole de Modelisation, 1-110, Note du Pôle de modélisation de l'Institut PierreSimon Laplace No 27, https://doi.org/10.1029/137GM07, 2008.

Martínez-Garcia, A., Rosell-Melé, A., McClymont, E. L., Gersonde, R., and Haug, G. H.: Subpolar link to the emergence of the modern equatorial Pacific cold tongue, Science, 328, 15501553, https://doi.org/10.1126/science.1184480, 2010.

Mathiot, P., Barnier, B., Gallée, H., nes, J. M. M., Sommer, J. L., Juza, M., and Penduff, T.: Introducing katabatic winds in global \{ERA40\} fields to simulate their impacts on the Southern Ocean and sea-ice, Ocean Model., 35, 146-160, https://doi.org/10.1016/j.ocemod.2010.07.001, 2010. 
McClymont, E. L. and Rosell-Melé, A.: Links between the onset of modern Walker circulation and the mid-Pleistocene climate transition, Geology, 33, 389-392, 2005.

McClymont, E. L., Rosell-Melé, A., Giraudeau, J., Pierre, C., and Lloyd, J. M.: Alkenone and coccolith records of the midPleistocene in the south-east Atlantic: implications for the index and South African climate, Quaternary Sci. Rev., 24, 1559-1572, https://doi.org/10.1016/j.quascirev.2004.06.024, 2005.

McCreary, J. and Lu, P.: Interaction between the subtropical and the equatorial ocean circulations: The subtropical cell., J. Phys. Oceanogr., 24, 466-497, 1994.

McManus, J., Francois, R., Gherardi, J.-M., Keigwin, L., and Brown-Leger, S.: Collapse and rapid resumption of Atlantic meridional circulation linked to deglacial climate changes, Nature, 428, 834-837, 2004.

Medina-Elizalde, M., Lea, D. W., and Fantle, M. S.: Implications of seawater $\mathrm{Mg} / \mathrm{Ca}$ variability for Plio-Pleistocene tropical climate reconstruction, Earth Planet. Sc. Lett, 269, 585-595, https://doi.org/10.1016/j.epsl.2008.03.014, 2008.

Meehl, G. A., Arblaster, J. M., Fasullo, J. T., Hu, A., and Trenberth, K. E.: Model-based evidence of deep-ocean heat uptake during surface-temperature hiatus periods, Nature Climate Change, 1, 360-364, 2011.

Melles, M., Brigham-Grette, J., Minyuk, P. S., Nowaczyk, N. R., Wennrich, V., DeConto, R. M., Anderson, P. M., Andreev, A. A., Coletti, A., Cook, T. L., Haltia-Hovi, E., Kukkonen, M., Lozhkin, A. V., Rosen, P., Tarasov, P., Vogel, H., and Wagner, B.: 2.8 Million Years of Arctic Climate Change from Lake El-gygytgyn, NE Russia, Science, 337, 315-320, https://doi.org/10.1126/science.1222135, 2012.

Naafs, B. D. A., Hefter, J., Grützner, J., and Stein, R.: Warming of surface waters in the mid-latitude North Atlantic during Heinrich events, Paleoceanography, 28, 153-163, https://doi.org/10.1029/2012PA002354, 2013.

Naish, T., Powell, R., Levy, R., Wilson, G., Scherer, R., Talarico, F., Krissek, L., Niessen, F., Pompilio, M., Wilson, T., Carter, L., DeConto, R., Huybers, P., McKay, R., Pollard, D., Ross, J., Winter, D., Barrett, P., Browne, G., Cody, R., Cowan, E., Crampton, J., Dunbar, G., Dunbar, N., Florindo, F., Gebhardt, C., Graham, I., Hannah, M., Hansaraj, D., Harwood, D., Helling, D., Henrys, S., Hinnov, L., Kuhn, G., Kyle, P., Lufer, A., Maffioli, P., Magens, D., Mandernack, K., McIntosh, W., Millan, C., Morin, R., Ohneiser, C., Paulsen, T., Persico, D., Raine, I., Reed, J., Riesselman, C., Sagnotti, L., Schmitt, D., Sjunneskog, C., Strong, P., Taviani, M., Vogel, S., Wilch, T., and Williams, T.: Obliquity-paced Pliocene West Antarctic ice sheet oscillations, Nature, 458, 322328, 2009.

Nicolas, J. P., Vogelmann, A. M., Scott, R. C., Wilson, A. B., Cadeddu, M. P., Bromwich, D. H., Verlinde, J., Lubin, D., Russell, L. M., Jenkinson, C., Powers, H. H., Ryczek, M., Stone, G., and Wille, J. D.: January 2016 extensive summer melt in West Antarctica favoured by strong El Niño., Nat. Commun., 8, 15799, https://doi.org/10.1038/ncomms15799, 2017.

Otto-Bliesner, B. L., Brady, E., Shin, S.-I., Liu, Z., and Shields, C.: Modeling El Niño and its tropical teleconnections during the last glacial cycle, Geophys. Res. Lett., 30, 2198, https://doi.org/10.1029/2003GL018553, 2003.

Park, W., Keenlyside, N., Latif, M., Ströh, A., Redler, R., Roeckner, E., and Madec, G.: Tropical Pacific climate and its response to global warming in the Kiel climate model, J. Climate, 22, 71-92, 2009.

Peltier, W. and Solheim, L.: The climate of the Earth at Last Glacial Maximum: statistical equilibrium state and a mode of internal variability, Quaternary Sci. Rev., 23, 335-357, https://doi.org/10.1016/j.quascirev.2003.07.003, 2004.

Pollard, D. and DeConto, R.: Modelling West Antarctic ice sheet growth and collapse through the past five million years, Nature, 458, 329-332, https://doi.org/10.1038/nature07809, 2009.

Rahmstorf, S., Feulner, G., Mann, M. E., Robinson, A., Rutherford, S., and Schaffernicht, E. J.: Exceptional twentieth-century slowdown in Atlantic Ocean overturning circulation, Nature Climate Change, 5, 475-480, 2015.

Raymo, M., Grant, B., Horowitz, M., and Rau, G.: Mid-Pliocene warmth: stronger greenhouse and stronger conveyor, Mar. Micropaleontol., 27, 313-326, 1996.

Rayner, N. A., Parker, D. E., Horton, E. B., Folland, C. K., Alexander, L. V., Rowell, D. P., Kent, E. C., and Kaplan, A.: Global analyses of sea surface temperature, sea ice, and night marine air temperature since the late nineteenth century, J. Geophys. Res.-Atmos., 108, 4407, https://doi.org/10.1029/2002JD002670, 2003.

Reynolds, R. W., Rayner, N. A., Smith, T. M., Stokes, D. C., and Wang, W.: An improved in situ and satellite SST analysis for climate, J. Climate, 15, 1609-1625, 2002.

Roychowdhury, R. and DeConto, R. M.: Interhemispheric bias in earth's climate response to orbital forcing, Clim. Past Discuss., https://doi.org/10.5194/cp-2015-156, 2016.

Russon, T., Elliot, M., Sadekov, A., Cabioch, G., Corrège, T., and De Deckker, P.: The mid-Pleistocene transition in the subtropical southwest Pacific, Paleoceanography, 26, pA1211, https://doi.org/10.1029/2010PA002019, 2011.

Scherer, R. P., Bohaty, S. M., Dunbar, R. B., Esper, O., Flores, J.-A., Gersonde, R., Harwood, D. M., Roberts, A. P., and Taviani, M.: Antarctic records of precession-paced insolation-driven warming during early Pleistocene Marine Isotope Stage 31, Geophys. Res. Lett., 35, L03505, https://doi.org/10.1029/2007GL032254, 2008.

Schilt, A., Baumgartner, M., Blunier, T., Schwander, J., Spahni, R., Fischer, H., and Stocker, T. F.: Glacial-interglacial and millennial-scale variations in the atmospheric nitrous oxide concentration during the last 800,000 years, Quaternary Sci. Rev., 29, 182-192, 2010.

Schmitt, R., Bogden, P., and Dorman, C.: Evaporation minus precipitation and density flux for the North Atlantic, J. Phys. Oceanogr., 19, 1208-1221, 1989.

Severijns, C. A. and Hazeleger, W.: The efficient global primitive equation climate model SPEEDO V2.0, Geosci. Model Dev., 3, 105-122, https://doi.org/10.5194/gmd-3-105-2010, 2010.

Shin, S.-I., Liu, Z., Otto-Bliesner, B., Brady, E. C., Kutzbach, J. E., Harrison, S. P.: A simulation of the Last Glacial Maximum Climate using the NCAR CSM, Clim. Dynam., 20, 127-151, 2003.

Speer, K. and Tziperman, E.: Rates of water mass formation in the North Atlantic Ocean, J. Phys. Oceanogr., 22, 94-104, 1992.

Speich, S., Blanke, B., and Cai, W.: Atlantic meridional overturning circulation and the Southern Hemisphere supergyre, Geophys. Res. Lett., 34, 123614, https://doi.org/10.1029/2007GL031583, 2007.

Stepanov, V. N. and Haines, K.: Mechanisms of Atlantic Meridional Overturning Circulation variability simulated by the NEMO 
model, Ocean Sci., 10, 645-656, https://doi.org/10.5194/os-10645-2014, 2014.

Stössel, A., Kim, S.-J., and Drijfhout, S. S.: The impact of Southern Ocean sea ice in a global ocean model, J. Phys. Oceanogr., 28, 1999-2018, 1998.

Talley, D.: Shallow, intermediate, and deep overturning components of the global heat budget, J. Phys. Oceanogr., 35, 530-560, 2003.

Talley, D., Reid, L., and Robbins, E.: Data-Based Meridional Overturning Streamfunctions for the Global Ocean, J. Climate, 16, 3213-3226, 2003.

Timmermann, A., Latif, M., Voss, R., and Grötzer, A. M.: Northern Hemisphere Interdecadal Variability: A Coupled Air-Sea Mode, J. Climate, 11, 1906-1930, 1998.

Tomas, R. A., Deser, C., and Sun, L.: The Role of Ocean Heat Transport in the Global Climate Response to Projected Arctic Sea Ice Loss, J. Climate, 29, 6841-6859, 2016.

Valcke, S.: The OASIS3 coupler: a European climate modelling community software, Geosci. Model Dev., 6, 373-388, https://doi.org/10.5194/gmd-6-373-2013, 2013.

Vaughan, D. G. and Arthern, R.: Why Is It Hard to Predict the Future of Ice Sheets?, Science, 315, 1503-1504, https://doi.org/10.1126/science.1141111, 2007.

Villa, G., Lupi, C., Cobianchi, M., Florindo, F., and Pekar, S.: A Pleistocene warming event at $1 \mathrm{Ma}$ in Prydz Bay, East Antarctica: Evidence from ODP Site 1165, Palaeogeogr. Palaeocl., 260, 230 244, https://doi.org/10.1016/j.palaeo.2007.08.017, 2008.

Voelker, A. H., Salgueiro, E., Rodrigues, T., Jimenez-Espejo, F. J., Bahr, A., Alberto, A., Loureiro, I., Padilha, M., Rebotim, A., and Rohl, U.: Mediterranean Outflow and surface water variability off southern Portugal during the early Pleistocene: A snapshot at Marine Isotope Stages 29 to 34 (1020-1135 ka), Global Planet. Change, 133, 223-237, https://doi.org/10.1016/j.gloplacha.2015.08.015, 2015.
Wang, C., Weisberg, R. H., and Yang, H.: Effects of the wind speedevaporation-SST feedback on the El Niño-Southern Oscillation, J. Atmos. Sci., 56, 1391-1403, 1999.

Wet, G., Castañeda, I. S., DeConto, R. M., and Brigham-Grette, J.: A high-resolution mid-Pleistocene temperature record from Arctic Lake El'gygytgyn: a $50 \mathrm{kyr}$ super interglacial from MIS 33 to MIS 31, Earth Planet. Sc. Lett., 436, 56-63, 2016.

Wijffels, S., Toole, J., Bryden, H., Fine, R., Jenkins, W., and Bullister, J.: The water masses and circulation at $10 \mathrm{~N}$ in the Pacific, Deep-Sea Res. Pt. I, 43, 501-544, https://doi.org/10.1016/09670637(96)00006-4, 1996.

Wood, R. A., Keen, A. B., Mitchell, J. F., and Gregory, J. M.: Changing spatial structure of the thermohaline circulation in response to atmospheric $\mathrm{CO}_{2}$ forcing in a climate model, Nature, 399, 572-575, https://doi.org/10.1038/21170, 1999.

Yin, Q.: Insolation-induced mid-Brunhes transition in Southern Ocean ventilation and deep-ocean temperature, Nature, 494, 222-225, https://doi.org/10.1038/nature11790, 2013.

Yin, Q. Z. and Berger, A.: Individual contribution of insolation and $\mathrm{CO}_{2}$ to the interglacial climates of the past 800000 years, Clim. Dynam., 38, 709-724, https://doi.org/10.1007/s00382011-1013-5, 2012.

Zhang, Y., Wallace, J. M., and Battisti, D. S.: Ensolike interdecadal variability: 1900-93, J. Climate, 10, 1004-1020, https://doi.org/10.1175/1520 0442(1997)010<1004:ELIV>2.0.CO;2, 1997 